InOedia $\quad \begin{aligned} & \text { InMedia } \\ & \text { The French Journal of Media Studies }\end{aligned}$

7.1. $\mid 2018$

Visualizing Consumer Culture

\title{
The World Cup and the Media
}

Some considerations following the international congress. "The World Cup, between Europe and the Americas", held in Paris (June 2018)

\section{Philippe Vonnard}

\section{Q OpenEdition \\ 1 Journals}

\section{Electronic version}

URL: http://journals.openedition.org/inmedia/1532

DOI: 10.4000/inmedia.1532

ISSN: 2259-4728

\section{Publisher}

Center for Research on the English-Speaking World (CREW)

\section{Electronic reference}

Philippe Vonnard, «The World Cup and the Media », InMedia [Online], 7.1. | 2018, Online since 20 December 2018, connection on 08 September 2020. URL : http://journals.openedition.org/inmedia/ 1532 ; DOI : https://doi.org/10.4000/inmedia.1532

This text was automatically generated on 8 September 2020

(c) InMedia 


\section{The World Cup and the Media}

Some considerations following the international congress. "The World Cup, between Europe and the Americas", held in Paris (June 2018)

\section{Philippe Vonnard}

1 June 2014. According to FIFA (the Fédération Internationale de Football association), around three billion people watched at least one minute of the World Cup (WC) Finalthe men's soccer world championship played every four year since $1930 .{ }^{1}$ Undoubtedly, the final of the WC is one of the most popular media events, very much akin to the opening ceremony of the Summer Olympic Games or the wedding of a member of the British royal family.

2 Many aspects of the WC media coverage have already been studied by researchers. Studies have notably been conducted on two main topics. Firstly, scholars have focused on the financial stakes and have particularly discussed the case of TV rights. In fact, since the first live broadcast of the WC in $1954,{ }^{2}$ the fees paid by the television channel to broadcast the games have increased with each tournament. Taking into account the constant development of national television but also the creation of supranational networks in the likes of Eurovision and then Mondiovision-which offered new possibilities to organize the broadcasting of the most important international sports events, like the Olympic Games or the World Cup-from the beginning of the 1960s, soccer leaders from both national and international organizations have negotiated with the television representatives to obtain money for broadcasting the games. The goals of the soccer leaders were, first, to use the money provided by the television networks to support some activities to develop soccer practice (for instance to organize conferences and training for coaches or referees and to support the travel of youth teams from small associations). The second goal was to limit the negative impact of television, particularly the possible loss of viewers-who were the main source of income for clubs and associations-with payment of a fee by the television to the clubs or to the national federations. ${ }^{3}$ During the 1970s and 1980s, a "commercial TV right turn" happened. In fact, new actors, mostly businessmen, headed the clubs, federations, and FIFA (for example João. Havelange and Joseph Blatter). For instance, Havelange, who was FIFA President from 1974 to 1998, had a clear idea on the subject. For him, TV rights should 
be used to support the new development program for the game (like GOAL) created by FIFA $^{4}$. This policy-which has been pursued by Havelange's successor, Joseph Blatter ${ }^{5}$ was encouraged by the creation of private television companies, such as Mediaset in Italy or Canal+ in France, which decided to invest in the game to gain market shares. Fabien Hoëppe notes that the fee paid by television companies to broadcast the WC was around 30 million euros in 1986. Twelve years later, this amount was around 94 million, and for the 2010 WC tournament, it was more than 2 billion euros. ${ }^{6}$ In 2010, the TV rights received by FIFA is 67 times what it had been twenty-five years before!

Secondly, scholars have emphasized the fact that soccer has played an important role in the development of television itself. The first director of the Eurovision Programme Commission, Swiss Marcel Bezençon, indicated that if the Eurovision network was launched on June 1954, it was mainly due to the World Cup being played at that time. ${ }^{7}$ Four years later, the organization of the World Cup in Sweden was the opportunity to make some technical improvements which permitted the country to join the Eurovision network. ${ }^{8}$ Fabio Chisari has effectively indicated how the 1966 England WC was a turning point in regard to the link between television and soccerbecause for the first time, the organizers took into account the importance of television. Thus, they decided to do some work to the stadium (notably to improve camera location) and dedicated more space to the TV and radio commentators. ${ }^{9}$ This choice contributed to improving the quality of games broadcasting and also made some technical inventions possible. In the meantime, the industry used the event as a publicity tool for television, which encouraged increased television sales in Western Europe. This kind of "figuration" was then reproduced at each tournament. Thanks to this connection with television-and of course with other media like the press, radio and more recently, the Internet-the WC has become a "mega event", defined in the canonic studies by Maurice Roche as "largescale cultural (including commercial and sporting) events which have a dramatic character, mass popular appeal and international significance." 10

In parallel to the opening of the last World Cup played in June 2018 in Russia, an international congress was held in Paris at the University Paris III Sorbonne Nouvelle. ${ }^{11}$ The aim of this event was to discuss the multiple stakes (politic, economic, social) of the World Cup organization. In fact, until now authors have mainly focused on the political stakes of this mega event. ${ }^{12}$ Furthermore, while some tournaments like Italia 1934, Argentina 1978 or France 1998 are well studied, others such as Switzerland 1954, Sweden 1958, Chile 1962 or Mexico 1970 and 1986 are clearly under-researched. Another major goal of the conference was to offer a first reflection on topics which are still less investigated by historians-in comparison with Olympic Games studies-such as the legacy of the tournament and the failed applications. Around twenty researchers from twelve countries (young and more experienced scholars) came to discuss innovative studies during two days of lively exchanges. ${ }^{13}$ While, very much in contrast with other recent works around the $\mathrm{WC}^{14}$, the media were not at the center of this global perspective on World Cup history, the topic was not however absent from the debate. Three points can be developed regarding the brief and not exhaustive state of the art summarized in the first section of this text.

5 Firstly, speakers confirmed the importance of media coverage of the WC since its beginnings in 1930. In fact, the sport and mainstream press in the host country, but also in its neighboring countries, were clearly invested in the event. That is why it is important for instance to break with a Eurocentric view regarding the first World Cup 
held in Uruguay because, though the media coverage of the event was limited in the European press, in the "Cono Sur", the tournament received considerable media coverage. Thus, the idea of a "small event" developed by European researchers has to be revised based on the importance given to the WC in the media of Argentina, Brazil, and Uruguay. Furthermore, and concerning television more specifically, it seems that following the decision taken by the organizers of the 1966 WC, Mexico 1970 can be seen as the real accelerator of the partnership between soccer and television: for the first time, the WC was broadcast in color and some games were played at noon to allow European citizens to watch the tournament more easily.

6 Secondly, one interesting point that still warrants further investigation, was the focus of some papers: the fact that key media actors have been directly involved in the organizational committee of the WC. It is well known that the media actively participated in the creation of sports competitions; the most famous example is the Tour de France created by newspaper L'Auto in $1903 .{ }^{15}$ But regarding the WC, this point is still not very much studied. For instance, the Swiss journalist, Humbert-Louis Bonardelly--director of one of the most important weekly sports magazine in the country, La Semaine sportive-had strong links with the organizing committee of the 1954 WC, according to letters found in the archives of the Swiss national football association. Since 1952, many articles about the organization of the tournament were published in La semaine sportive and editorials criticized the local or national, authorities for the lack of financial support, notably to build a new stadium. In the meantime, journalists also developed some moral arguments around the tournament (it would be an important event for the youth of the country). Moreover, some months before what was considered by the Swiss press to be the "most important sports event of the year", many articles were published in La Semaine sportive about the foreign teams and also about the Swiss national teams. It is a clear case of how the press built a discourse to dramatize the event. If the press had obviously its own interest to increase sales, it was also necessary to generate publicity for the tournament in order to fill stadiums ${ }^{16}$ Close to the organization committee, Bonardelly knew that due to the small size of Switzerland, it was a real factor in the success of the event. Thus, his newspaper could be used to answer this challenge. On this point, Mexico 1970 and 1986 made a step forward due to the strong connections between the organizing committee and the media because one of the top leaders of Telesistema Mexicano ${ }^{17}$-the most important television channel of the country-Guillermo Cañedo de la Bárcena was directly involved in the organizing committee. Cañedo, who also participated in 1971 in the creation of the Organización de Televisión Iberoamericana (OTI) which covered the majority of Latin American countries, was one of the key actors in soccer in Mexico and was also vice-president of FIFA. His position inside FIFA allowed him to easily negotiate the rights for broadcasting the event but also helped Mexico to obtain the 1986 WC despite the strong lobbying of the United States. ${ }^{18}$

Otherwise, and this is the third point noted by the speakers, the media helped to build the image of a country or a city. The role of soccer, and particularly the national team, as a vector of national identity is well studied. ${ }^{19}$ Here, speakers proposed new ideas on the topic and showed that the press can also build national pride by creating a bad image of the "foe", for example when the WC application failed. This was the case in the Argentinian press regarding Chile, the country that won the race for the 1962 WC organization; or in the United Stated vis-à-vis FIFA, when the institution decided to give the 1986 WC to Mexico. Moreover, a World Cup is not only a global or national event, it 
is also a local one. In fact, for a city, hosting the games could be a wonderful opportunity to create a new image. For instance, in 1966 local newspapers from the city of Sheffield-whose public reputation was as an industrial site from the North of England-indicated with much enthusiasm that the WC games played in the city put Sheffield at the "center of Europe" on certain days. It was of course not innocent to use this vocabulary in a time when England was discussing the possibility of joining the European Economic Community (EEC), to help create a modern and cosmopolitan image of the city.

8 All these points of course need further development in the future. Additionally, access to new materials with the progressive digitalization (by state or private actors) of radio and TV programs is another important aspect that was not raised during the conference, but which will surely offer new possibilities for researchers who focus on the relationship between the WC and the media. Thus, and for the $2022 \mathrm{WC}$, a scientific event will perhaps focus on what could be seen as the visual turn in sport history studies, resulting from the intensive coverage of sport in radio and television.

$9 \quad{ }^{1}$ https://www.eurosport.fr/economie/un-milliard-de-telespectateurs-pour-la-finalede-la-coupe-du-monde-2014_sto5031095/story.shtml, page consulted on 21st October 2018. On the creation and development of the World Cup, see: Alfred Wahl, Histoire de la Coupe du monde de football: une mondialisation réussie (P.I.E. Peter Lang: Brussels, 2012).

$10 \quad{ }^{2}$ Ten games were broadcast live within the Eurovision network created the same year. See: Jean-Christophe Meyer, "La fondation du 'La fondation du 'Grand Stade'. De la triomphale retransmission en direct de la Coupe du monde 1954 et de ses avatars dans les pays membres de l'Eurovision (1954-1958)", Traverse. Revue d'histoire, 26 (May 2016): 49-59.

$11 \quad{ }^{3}$ Few studies have focused on these relationships between football, and more generally sports leaders and television promoters. For an overview, see: Jürgen Mittag and JörgUwe Nieland. "Auf der Suche nach Gesamteuropa: UEFA und EBU als Impulsgeber der Europäisierung des Sports", in Freunde oder Feinde? Sportberichterstattung in Ost und West während des Kalten Kriegs, eds. Christoph Bertling and Evelyn Mertin (Gütersloh: Medienfabrik Gütersloh, 2013), 208-229. And for a case study (the broadcasting of the final of the European Champions' Clubs Cup), see: Philippe Vonnard and Léonard Laborie, "De l'événement au rendez- vous médiatique européen. L'UEFA, l'UER et la Coupe des clubs champions de soccer (1956-1968)", Vingtième siècle. Revue d'histoire, in press.

$12{ }^{4}$ In 2006, an investigative journalist called Andrew Jennings launched a direct attack on Havelange in a book alleging numerous cases of bribery and vote rigging. Following an investigation by the Swiss authorities and constant critics from his detractors led finally Havelange to resign his honorary presidency of FIFA. See: Andrew Jennings, Foul! The Secret World of FIFA, Bribes, Vote Rigging and Ticket Scandal (London: Routledge, 2006); Alan Tomlinson, FIFA. The Men, the Mythes and the Money (Oxford: Routledge, 2014).

$13{ }^{5}$ On this change of management at the top of FIFA, see: Philippe Vonnard and Nicola Sbetti, "João Havelange. A Businessman for World Soccer", in Leaders of International Sport Organizations. A Biographical Analysis of International Sport, eds. Emmanuel Bayle and Patrick Clastres (Basingstoke: Palgrave Macmillan, 2018), 127- 151.

$14{ }^{6}$ Fabien Hoëppe, “Droits TV: l'inflation”, Jurisport, 98 (printemps 2010): 29. 
$15{ }^{7}$ Marcel Bezançon. "L'Eurovision est-elle un mythe ?", UER. Bulletin de documentation et d'information, 5 (May-June 1954): 590. It seems that Marcel Bezençon could have had some links with Swiss soccer association leaders that could also have explained the possibility to achieve this. Further investigations have to be conducted on this point. Thanks to François Vallotton for this suggestion.

8 “Pour fêter son entrée dans l'Eurovision, la TV suédoise a choisi la Coupe du Monde", Télévision programme Magazine, 137 (8-14 June 1958).

${ }^{9}$ Fabio Chisari, “Quand le football s'est mondialisé : la retransmission télévisée de la Coupe du monde 1966", Histoire \& Société : revue européenne d'histoire sociale, 18-19, (printemps 2006): 222-237.

${ }^{10}$ Maurice Roche, Mega-events \& Modernity. Olympics and Expos in the Growth of Global Culture (London: Routledge, 2000), 1.

${ }^{11} \mathrm{http}: / /$ www.univ-paris3.fr/la-coupe-du-monde-de-football-entre-europe-etameriques-enjeux-acteurs-et- temporalites-d-un-evenement-global-xxe-xxiesiecle--474229.kjsp

${ }^{12}$ For instance: Paul Dietschy, Stéphane Mourlane and Ivan Gastaut, Histoire politique des Coupes du monde de football (Paris: Vuibert, 2006) ; Alfred Wahl, ed, Aspects de l'histoire de la coupe du monde de football (Metz: University of Metz, 2007) ; Stefan Rinke and Kay Schiller, eds., The FIFA World Cup 1930-2010. Politics, Commerce, Spectacle and Identities (Göttingen: Wallstein Verlag, 2014) ; Riccardo Brizzi and Nicola Sbetti, Storia della Copa del Mondo di Calcio (1930-2018) (Florence: Le Monnier, 2018).

13 The papers will be published in a special issue of the journal Soccer \& Society coordinated by Clément Astruc, Lorenzo Jalabert D'Amado, Nicola Sbetti and Philippe Vonnard. A review of the discussion held during the congress has been written by Yannick Deschamps for the journal Vingtième siècle. Revue d'histoire and will be available soon.

${ }^{14}$ Kausik Bandyopadhyay, Souvik Naha and Shakya Mitra, eds, "Special issue: FIFA World Cup and Beyond: Sport, Culture, Media and Governance", Sport in Society, 20 (May-June 2017).

${ }^{15}$ Fabien Wille, Le Tour de France : un modèle médiatique (Paris: Presses Universitaires du Septentrion, 2003). See also : Gilles Montérémal, “L’Equipe : médiateur et producteur de spectacle sportif (1946-1967)”, Le Temps des Médias, 9 (May 2007): 107-120.

${ }^{16}$ Philippe Vonnard and Grégory Quin, “A Touristic Event? Some considerations about the 1954 WC",

Entreprises et histoire, in press.

${ }^{17}$ In 1973, it became Televisa.

${ }^{18}$ Initially, the 1986 WC had been given to Colombia. But due to the difficult political context that existed in the country and which created many difficulties around organizing the event, the WC was finally reallocated to Mexico.

${ }^{19}$ For a recent publication, see : Fabien Archambault, Stéphane Beaud and William Gasparini, eds, Le football des nations. Des territoires de jeu aux communautés imaginées (Paris: Publications de la Sorbonne, 2016). And for the relationship between the building of identity and the press, see notably: Liz Crolley and David Hand, eds, Football, Europe and the Press (London: F. Cass, 2002). 


\section{AUTHOR}

\section{PHILIPPE VONNARD}

Philippe Vonnard holds a PhD. in Sport Sciences and Physical Education (University of Lausanne, Switzerland) and he is currently SNSF senior researcher at the University of Lausanne. His work focuses on the internationalization of sport, and particularly on the Europeanization of soccer. He has already published several articles on this topic and has coordinated Building Europe with the Ball (Oxford, Peter Lang, 2016), Beyond Boycotts (de Gruyter, 2017), Des hommes et des réseaux. Le rôle de la Suisse dans l'internationalisation du sport (Alphil, sous presse) and has written L'Europe dans le monde du football (Peter Lang, 2018). He is an active member of the RERIS network (www.reris.net). 